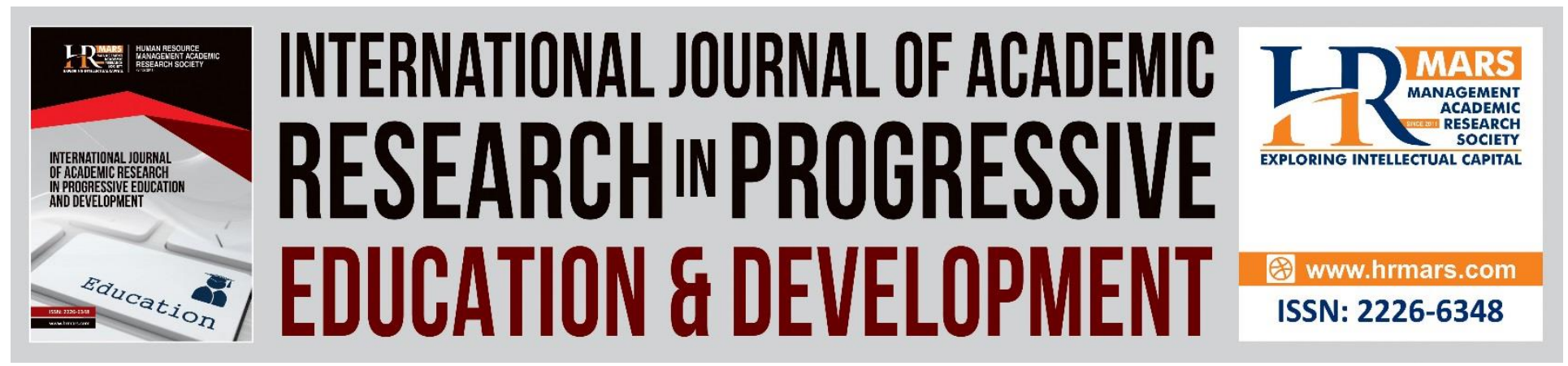

\title{
Training and Teaching of Arabic Translation Course in IPG: Perspectives of Trainees and Trainers
}

Nazirah Radin Salim, Idris Mansor

To Link this Article: http://dx.doi.org/10.6007/IJARPED/v7-i4/5330

DOI: $10.6007 /$ IJARPED/v7-i4/5330

Received: 17 Nov 2018, Revised: 28 Dec 2018, Accepted: 03 Jan 2019

Published Online: 10 Jan 2019

In-Text Citation: (Salim \& Mansor, 2018)

To Cite this Article: Salim, N. R., \& Mansor, I. (2018). Training and Teaching of Arabic Translation Course in IPG: Perspectives of Trainees and Trainers. International Journal of Academic Research in Progressive Education and Development, 7(4), 364-375.

Copyright: (C) 2018 The Author(s)

Published by Human Resource Management Academic Research Society (www.hrmars.com)

This article is published under the Creative Commons Attribution (CC BY 4.0) license. Anyone may reproduce, distribute, translate and create derivative works of this article (for both commercial and non-commercial purposes), subject to full attribution to the original publication and authors. The full terms of this license may be seen at: http://creativecommons.org/licences/by/4.0/legalcode

\section{Vol. 7, No. 4, 2018, Pg. 364 - 375}

Full Terms \& Conditions of access and use can be found at http://hrmars.com/index.php/pages/detail/publication-ethics 


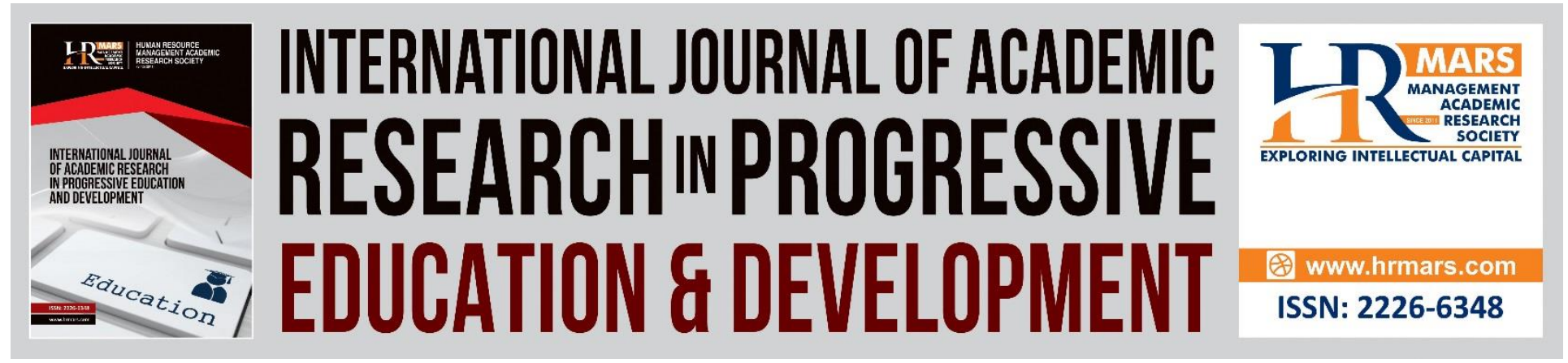

\title{
Training and Teaching of Arabic Translation Course in IPG: Perspectives of Trainees and Trainers
}

\author{
Nazirah Radin Salim \\ Department of Islamic and Moral Education, IPG Tuanku Bainun Campus, 14000, Bukit \\ Mertajam, Penang \\ Email: nazirahradin@gmail.com
}

Idris Mansor

(Corresponding Author)

Section of Translation Studies and Interpreting, School of Humanities, Universiti Sains Malaysia,

11800 USM Penang.

Email: idrismansor@usm.my

\begin{abstract}
As the dimension of this borderless world gets smaller, translation is seen as an important medium of communication. An effort with regard to translation has to be made, especially in relation to training for translators. Therefore, this study was conducted to carry out an initial survey of the training and teaching of translation among students majoring in Arabic language at the Institut Pendidikan Guru (IPG). The instruments used in this study are document analysis as well as a simple survey involving students majoring in Arabic language and translation course lecturers. The findings indicated that translation courses are offered to students majoring in Arabic language at the preparatory level (PPISMP) in seven of the total of twenty-seven IPG nationwide. The findings also showed that most respondents felt that translation activity is very important, hence advanced translation courses should be offered at the degree level (PISMP). In conclusion, it is important to make the shift in the training and teaching of translation courses at IPG by making improvements in some specific areas.
\end{abstract}

Keywords: Translation Training, Teaching Of Translation, Ipg, Trainer, Trainee.

\section{INTRODUCTION}

Language is a cultural element that has become a means of communication to convey or receive a message. Language is also a tool for one to present ideas, disseminate knowledge, convey thoughts and transfer certain information to others whether through speech, in writing, gestures, symbols or signs. However, as today's dimension of time and the borderless world get smaller, 
INTERNATIONAL JOURNAL OF ACADEMIC RESEARCH IN PROGRESSIVE EDUCATION AND

DEVELOPMENT

Vol. 7, No. 4, 2018, E-ISSN: 2226-6348 @ 2018 HRMARS

communication in a universe that is rich with a treasury of languages will certainly involve interlingual communication.

One way to allow interlingual communication between people of various races and across cultures is through translation. Komissarov (1991: 33) referred to this situation as the raison d'etre of translation (reason to be translated), that is the need to translate to enable interaction between societies of different languages.

Since translation is seen as one of the most important communication media, efforts regarding translation must be made, particularly in relation to training for translators. The reason is that the use of language whether in writing or speech is a dynamic process that sometimes involves analogies and metaphors. For instance, the metaphorical and symbolic meanings of a lion can lead to misunderstandings between the Arab and Malay societies, which have different cultures. In the Arab society, the lion is a symbol of valour, but in the Malay society, a lion is used in reference to a fierce person. Thus, students who are not proficient in cultural aspects often misinterpret the sentence كالأسد المعلم [al-Muallim ka al-asad] 'the teacher is like a lion = the teacher is as brave as a lion' as 'the teacher is as fierce as a lion'. The use of language by analogy and metaphor can cause serious misunderstanding in a society that speaks a different language if the translator does not play his or her role competently. A competent and qualified translator is usually the result of a series of training and teaching of translation that has been well planned, organised and implemented, whether in college, institution of learning or university.

Therefore, the objective of this study is to identify the form of training and teaching of translation offered by the Institut Pendidikan Guru (IPG), Ministry of Education Malaysia. This study was based on a preliminary survey obtained through documentary analysis and a questionnaire involving twenty-seven students and five lecturers from four IPG in Malaysia. The questionnaires distributed are related to some issues concerning the training and teaching of translation at those institutions.

\section{TRANSLATION TRAINING AND TEACHING}

In recent years, the current demands of globalisation emphasise the critical need for capable and professional translators. As such, the knowledge of a student who wants to become a translator must also expand to keep abreast with these demands. The reason is that the knowledge of a student should not only revolve around dual-language alone, but also encompasses a multitude of translation knowledge that are able to meet the interlingual communication needs of the current era while qualifying the student to apply for various posts in a translation agency or become a freelance translator (Fanany 2003: 444; Gouadec, 2015: 438).

According to Hurtado Albir (2015: 257), given the changes taking place in the translation profession as well as academic progression, a form of training that can meet the current social needs and international scope is direly needed. Thus, the teaching of translation based on competence training (Honig, 1998: 88; Ressurreccio, Piorno \& Izquierdo, 2008: 2; Hurtado Albir, 2015: 257 ) that is contemporary and the most updated should be emphasised. Currently, most translation training programmes seem to have the goal of producing qualified and competent 
DEVELOPMENT

Vol. 7, No. 4, 2018, E-ISSN: 2226-6348 ๑ 2018 HRMARS

translators. The programmes include transforming students with proficiency in a specific language into professionals who can translate and revise, among other things (Gambier, 2012: 164). Meanwhile, Bell (2016: 8) stressed that translation is an activity that can promote language learning among undergraduate students. This scenario can also improve a student's ability to handle two languages, encourage cross-cultural understanding, and enhance skills in translation techniques.

Hurtado Albir (2015), a scholar who often discusses the aspects of training in translation, presented a working paper on a more comprehensive and dynamic translation curriculum involving competencies, assignments, and assessment in translation training. Hurtado Albir (2015: 256) recommended the use of the competence-based pedagogical approach, where four levels of translation training are suggested, namely:

1) Competence-Based Training - CBT: A CBT curriculum with the features of an integrated approach to teaching, learning, and assessment that revolves around the aspects of competencies. CBT is based on cognitive constructivist and socio-constructivist learning theories that aim to make learning more meaningful.

2) Specific competencies for translator training: Specific competencies encompass methodological and strategic competencies, contrastive competency, extralinguistic competency, occupational competency, instrumental competency, and translation problem-solving competency. Each category reflects the classification of each competency that determines the features of the curriculum design.

3) Methodological framework and curriculum design (task-based approach): The main aim of the task-based approach is to enable the scope of curriculum design to integrate the different elements that include learning objectives, content, methodology, and assessment.

4) Competence assessment: In CBT, assessment is regarded as more of a learning tool than merely a grading system. There are several types of assessment to choose from, whether based on purpose (summative/diagnostic/formative), timing (initial assessment/continuous assessment/final assessment), or assessor (self-assessment/peer assessment/hetero-assessment, i.e. an assessment between two people with varying translation skills, e.g. a lecturer assesses a student).

Hurtado Albir's (2015) CBT concept paper is seen as a new dimension in the aspect of translation training, competency acquisition, and the teaching of translation, especially in familiarising apprentice translators with professional practices. The working paper provides a complete guide in designing the syllabus or curriculum of translation training, as it covers the entire process starting from the proposed competence acquisition model until the last aspect, that is, assessment. 
Vol. 7, No. 4, 2018, E-ISSN: 2226-6348 ๑ 2018 HRMARS

Also, extra activities can be organised to encourage students' participation in translation. Gambier (2012: 164), for example, suggested that translation training is initiated at the university level including advanced training, intensive training, self-training, distance learning, and lifelong learning. He also suggested several deductive approaches in the acquisition and improvement of translation competencies, among them process-centred activities, such as:

1) Activities that help students to reflect on their principles on translation, as well as to reflect on their self-concept of translators.

2) Activities that motivate students, for example, a student's intuition regarding ways of thinking and creativity that can reduce learning anxiety.

3) Activities that help students to appreciate the importance of understanding through reading. Indeed, a translator is not just a reader and information seeker but should also have a sense of allusions, double meanings, ambiguities, connotations, polysemy and others.

Bell (2016: 16) proposed some measures that can be taken to achieve the expected goals in the translation field in Malaysia. Some of the measures are making translation a staple activity in language learning, providing a postgraduate training programme that can produce professional translators, and establishing a truly functional and trustworthy 'Association of Professional Translators'.

\section{TRAINING AND TEACHING OF ARABIC LANGUAGE TRANSLATION IN IPG}

Institut Pendidikan Guru (IPG) is one of the higher educational institutions in Malaysia that have already taken up the measure suggested by Bell (2016), that is, offering translation courses to students majoring in languages including the Arabic language. Students majoring in Arabic language in IPG are regarded as students who learn a foreign language as a second language. Therefore, a translation course is offered to Arabic language students to build their translation skills, as well as helping them to master a second language better. Statistical data from the Student Information System on 30 March 2018 produced by the Centre for Research, Development and Innovation (2018) revealed that 325 students were majoring in Arabic language at seven IPG that offer Arabic language major out of a total of twenty-seven IPG nationwide. Table 1 shows the distribution of the students majoring in Arabic language at the seven IPG: 
INTERNATIONAL JOURNAL OF ACADEMIC RESEARCH IN PROGRESSIVE EDUCATION AND DEVELOPMENT

Vol. 7, No. 4, 2018, E-ISSN: $2226-6348$ @ 2018 HRMARS

Table 1:

Distribution of Students Majoring in Arabic Language at Seven IPG that Offer Arabic Language Major

\begin{tabular}{cllc}
\hline No. & \multicolumn{1}{c}{ IPG } & \multicolumn{1}{c}{ PISMP*/PPISMP** } & Total \\
\hline 1. & Kampus Pendidikan Islam, Bangi, Selangor. & PISMP (114 students) & 172 \\
& & PPISMP (58 students) & \\
\hline 2. & Kampus Darulaman, Jitra, Kedah. & $\begin{array}{l}\text { PISMP (46 students) } \\
\text { PPISMP (40 students) }\end{array}$ & \\
\hline 3. & Kampus Perempuan Melayu, Melaka & PISMP & 15 \\
\hline 4. & Kampus Perlis, Perlis. & PISMP & 14 \\
\hline 5. & Kampus Sultan Mizan, Besut, Terengganu. & PISMP & 13 \\
\hline 6. & Kampus Raja Melewar, Negeri Sembilan. & PISMP & 13 \\
\hline 7. & Kampus Sultan Abdul Halim, Sg. Petani. & PISMP & 12 \\
\hline \multicolumn{6}{c}{ GRAND TOTAL } & 325
\end{tabular}

*Bachelor's Degree Programme

*Bachelor's Degree Preparatory Programme

Of the 325 students majoring in Arabic language at the seven IPG, 227 of them were students of the Bachelor's Degree Programme (PISMP) in Arabic language. Meanwhile, 98 students were from the Bachelor's Degree Preparatory Programme (PPISMP) in Arabic language. The PPISMP and PISMP students were from various intakes, and they took up the translation course in the second semester of the PPISMP level. Table 2 shows the number of PISMP and PPISMP students and the semester when they took up the translation course.

Table 2:

Translation Course Learning Period among PISMP and PPISMP Students

\begin{tabular}{ccccc}
\hline No & Programme & Intake & $\begin{array}{c}\text { Translation Course } \\
\text { Learning Period }\end{array}$ & Total \\
\hline 1. & PISMP & $2014 / 2015 / 2016$ & Second semester of PPISMP & 227 \\
\hline 2. & PPISMP & 2017 & Second semester of PPISMP & 98 \\
\hline \multicolumn{2}{c}{ OVERALL TOTAL } & & 325 \\
\hline
\end{tabular}

The translation course that must be taken by students majoring in Arabic language at the IPG is 'Introduction to Arabic Language Lexicography and Translation'. This course is one of the mandatory core courses for students of Bachelor of Teaching Preparatory Programme (PPISMP) Arabic Language for Primary Education. Among the objectives of the translation course are to enable the students to:

i. explain the definition and basic theories of lexicography and translation concept of the Arabic language;

ii. translate texts from Arabic to Malay and vice versa creatively and consistently;

iii. elaborate the importance and the development factors of the field of Arabic language translation. 
INTERNATIONAL JOURNAL OF ACADEMIC RESEARCH IN PROGRESSIVE EDUCATION AND

DEVELOPMENT

Vol. 7, No. 4, 2018, E-ISSN: 2226-6348 @ 2018 HRMARS

Meanwhile, the synopsis of the course is as follows: '... This course presents the theory of translation in terms of the concept of translation, the pillars of translation, the importance of translation and its effectiveness, the development factors of translation, types of text, translation methods, methodology of translation, types of translation, and challenges in translation as well as the application of translation from Arabic to Malay and vice versa.' (Pusat Pembangunan Akademik, 2016: 1-3).

Based on the course objectives and synopsis, it can be said that the syllabus contains most of the necessary titles and basic aspects of translation, such as translation concept, the importance of translation, translation methods and methodology, as well as the types of text. These basic aspects are important and should be learnt by every student majoring in Arabic language at IPG. The reason is that an academic institution that offers translation training should prove that its goal is not merely to teach foreign languages to students but also to teach the best translation competencies (Honig, 1998: 88).

However, the offering of only one translation course to Arabic major students is seen as inadequate to achieve the desired goal. Moreover, the translation course is offered only to students at the preparatory level (PPISMP), who are seen as still in the early phase of language learning. Indeed, translation learning requires students to master several important aspects including the language aspect. As for the undergraduate (PISMP) students, no translation course is offered to them.

If we compare the offering of translation courses to undergraduate students majoring in Arabic language between the Institut Pendidikan Guru (IPG) and Universiti Pendidikan Sultan Idris (UPSI), UPSI is seen to be more ahead in offering translation courses to its students. UPSI requires its Bachelor in Arabic Language (Education) students to take three translation courses, which are 'Basic Translation: Theory and Practice', 'Arabic Lexicography', and 'Application of Malay-Arabic Translation' (Academic Handbook, 2016: 54- 55). On the other hand, students pursuing Bachelor of Teaching (Arabic Language) at IPG only take one translation course, namely 'Introduction to Arabic Language Lexicography and Translation'. A comparison of the offering of translation courses between IPG and UPSI is shown in Table 3 below: 
INTERNATIONAL JOURNAL OF ACADEMIC RESEARCH IN PROGRESSIVE EDUCATION AND DEVELOPMENT

Vol. 7, No. 4, 2018, E-ISSN: $2226-6348$ @ 2018 HRMARS

Table 3:

A Comparison of Translation Courses Offered at IPG and UPSI

\begin{tabular}{|c|c|c|}
\hline $\begin{array}{l}\text { Institution } \\
\text { / } \\
\text { Programm } \\
\quad \text { e }\end{array}$ & $\begin{array}{l}\text { Bachelor's Degree in Arabic } \\
\text { Language - Preparatory Level }\end{array}$ & $\begin{array}{c}\text { Bachelor's Degree in Arabic Language - } \\
\text { Degree Level }\end{array}$ \\
\hline IPG & $\begin{array}{l}\text { 1. Introduction to Arabic } \\
\text { Language Lexicography and } \\
\text { Translation }\end{array}$ & Not offered \\
\hline UPSI & (No preparatory level) & $\begin{array}{l}\text { 1. Basic Translation: Theory and } \\
\text { Practice } \\
\text { 2. Arabic Lexicography } \\
\text { 3. Application of Malay-Arab } \\
\text { Translation }\end{array}$ \\
\hline
\end{tabular}

The comparison between IPG and UPSI is considered appropriate because both institutions are education-based. For example, in addition to taking courses in specialised fields, students in both institutions need to take a course that is educational in nature, such as 'Computer-Aided Arabic Language Teaching' in UPSI and 'Methods of Teaching for Arabic Language Proficiency' in IPG.

\section{FINDINGS AND DISCUSSIONS}

To obtain the views of lecturers and students on translation training and learning among students majoring in Arabic language at IPG, an initial survey was conducted. Respondents consisted of twenty-seven students majoring in Arabic language and five lecturers of translation course at four IPG, and their views were gathered through a simple, brief questionnaire. Tables 4 and 5 show the findings obtained from the lecturers and the students, respectively: 
INTERNATIONAL JOURNAL OF ACADEMIC RESEARCH IN PROGRESSIVE EDUCATION AND DEVELOPMENT

Vol. 7, No. 4, 2018, E-ISSN: $2226-6348 @ 2018$ HRMARS

Table 4:

Mean and Standard Deviation for Lecturers' Perception of Training and Learning of Translation Course at IPG

\begin{tabular}{clccc}
\hline Item & \multicolumn{1}{c}{ Subject } & Mean & SD & $\begin{array}{c}\text { Interpretatio } \\
\text { n }\end{array}$ \\
\hline Lp 1 & $\begin{array}{l}\text { Translation course is important for students } \\
\text { majoring in Arabic language at IPG. }\end{array}$ & 4.80 & 0.447 & High \\
\hline Lp 2 & $\begin{array}{l}\text { The offering of translation course } \\
\text { (BAM1054*) to only PPISMP* Arabic } \\
\text { language students is insufficient. }\end{array}$ & 4.80 & 0.447 & High \\
\hline Lp 3 & $\begin{array}{l}\text { Translation course with a more in-depth } \\
\text { translation content should be extended to } \\
\text { PISMP* Arabic language students. }\end{array}$ & 5.00 & 0.000 & High \\
\hline Lp 4 & $\begin{array}{l}\text { Extra translation activities should be } \\
\text { organised on a periodic basis for Arabic } \\
\text { language students. }\end{array}$ & 4.80 & 0.447 & High \\
\hline Lp 5 & $\begin{array}{l}\text { BAM1054* translation course syllabus needs } \\
\text { to be improved. }\end{array}$ & 4.80 & 0.447 & High \\
\hline Lp 6 & $\begin{array}{l}\text { Translation titles and lexicography titles in } \\
\text { the BAM1054* course should be split into } \\
\text { two separate courses. }\end{array}$ & 4.80 & 0.447 & High \\
\hline
\end{tabular}

\section{$\mathrm{N}=5, \mathrm{Lp}=$ Lecturer part}

Table 4 shows that Item Lp3 (Translation course with a more in-depth translation content should be extended to PISMP* Arabic language students) has the highest mean value of 5.00 with a standard deviation of 0.000 . This shows that all five respondents strongly agreed that a translation course should also be offered to Arabic language undergraduate (PISMP) students.

Meanwhile, other items have the same mean and standard deviation of 4.80 and 0.447 , respectively. These items are Lp1 (Translation course is important for students majoring in Arabic language at IPG), Lp2 (The offering of translation course (BAM1054*) to only PPISMP* Arabic language students is insufficient), Lp4 (Extra translation activities should be organised on a periodic basis for Arabic language students), Lp5 (BAM1054* translation course syllabus needs to be improved), and Lp6 (Translation titles and lexicography titles in the BAM1054* course should be split into two separate courses). These results also show that all respondents have a high interpretation of each matter raised in the study questionnaire. 
INTERNATIONAL JOURNAL OF ACADEMIC RESEARCH IN PROGRESSIVE EDUCATION AND

DEVELOPMENT

Vol. 7, No. 4, 2018, E-ISSN: $2226-6348 @ 2018$ HRMARS

Table 5:

Mean and Standard Deviation for Students' Perception of Translation Training and Teaching Course at IPG

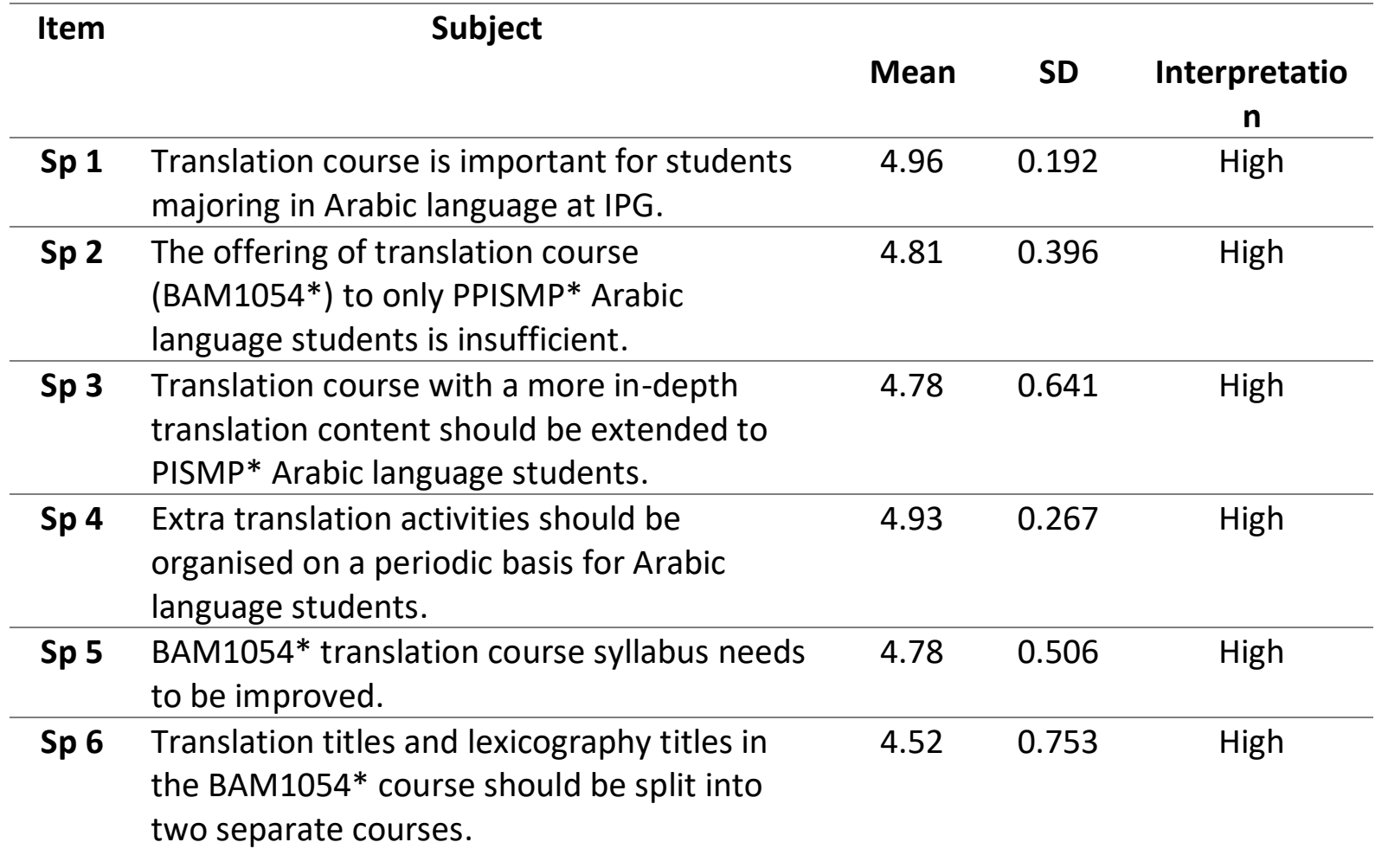

\section{$\mathrm{N}=27, \mathrm{Sp}=$ Student part}

Table 5 shows that Item Sp1 (Translation course is important for students majoring in Arabic language at IPG) is ranked the highest (mean: 4.96, standard deviation: 0192), followed by item Sp4 (Extra translation activities should be organised on a periodic basis for Arabic language students) with a mean value of 4.93 and standard deviation of 0.267 . Moreover, respondents also agreed with item Sp2, namely the offering of translation course (BAM1054*) to only PPISMP* Arabic language students is insufficient (mean: 4.81, standard deviation: 0.396) and item Sp3, namely translation course with a more in-depth translation content should be extended to PISMP* Arabic language undergraduate students with mean: 4.78 and standard deviation: 0.641 . The table also shows that all twenty-seven respondents have a high interpretation of each matter raised in the study questionnaire.

The findings of the questionnaire obtained from both groups of respondents, namely lecturers and students, show that the offering of a translation course in IPG is appropriate based on its importance to students majoring in Arabic language. This situation demonstrates that the offering of a translation course only at the preparatory level (PPISMP) is inadequate. Accordingly, this course should be extended to the bachelor's degree level (PISMP) with more specific and indepth content and translation topics. 
In organising translation courses to students, it is recommended that IPG shift towards several improvement processes in training and teaching of translation as proposed in the study questionnaire. Among them is updating the existing translation course syllabus, for example, incorporating elements of competence in the syllabus, separating translation titles and lexicography titles into two separate courses, and organising extra translation activities on a periodic basis to students majoring in Arabic language. These suggestions for improvement coincide with the recommendations of translation scholars such as Hurtado Albir (2015), who introduced competence-based training (CBT) and Gambier (2012), who suggested organising intensive training and self-training. These suggestions may also be forwarded to the management of IPG so that appropriate action can be taken.

\section{CONCLUSION}

In conclusion, the offering of translation courses to students majoring in languages at Institut Pendidikan Guru (IPG) is crucial even though the teaching of translation to them is not meant to produce specialists nor professional translators. Nonetheless, by learning the basic translation course, they have an advantage that could be considered as a starting point in pursuing the field. This is because a sound knowledge in the disciplines of translation will allow a translator to carry out his/her translation easier and more efficiently as well as achieving the expected goals. In fact, translators are considered as 'co-authors' with an important role in fulfilling the purpose and function of translation, such as the delivery of actual information according to the original meaning intended by the original author. The implication of the delivery of a translated text that deviates from the original meaning of the source text is it may cause misunderstanding to the target readers, especially if it involves sensitivity or certain norms of a society.

Therefore, to become a professional translator, the individual must undergo the specific course provided and be given a certificate of qualification as a translator. The skill as a translator can only be achieved through training especially formal training so that the translator is better prepared and better understands the needs and intricacies in producing translations. Therefore, the concerted efforts of numerous parties are crucial to assist individuals, trainee translators, and amateur translators to realize their desired goals.

\section{ACKNOWLEDGEMENT}

This work was supported in part by Bridging Grant of Universiti Sains Malaysia under Grant No: 304/PHUMANITI/6316197.

\section{REEFERENCES}

Bell, R.T. (2016). The place of translation in education and training in $21^{\text {st }}$ century society. In Zubaidah Ibrahim, Abdul Rahim Mat Yassim \& Supramani a/I Shoniah (Eds.). Kajian bahasa dan terjemahan (pp. 1-19). Kuala Lumpur: Penerbit Universiti Malaya.

Komunikasi, F. B. (2016). Buku Panduan Akademik. Tanjung Malim, Perak: Universiti Pendidikan Sultan Idris. 
Fanany, R. (2003). Developing highly skilled translators for the demands of the modern era. In Abdullah Hassan (Ed.). Terjemahan dalam bidang pendidikan (pp. 444-458). Tanjung Malim: Universiti Pendidikan Sultan Idris.

Gambier, Y. (2012). Teaching translation/ training translators. In Y. Gambier \& L. V. Doorslaer (Eds.). Handbook of translation studies (pp. 164-170). Amsterdam: John Benjamin Publishing Co.

Gouadec, D. (2015). Penterjemahan sebagai kerjaya (Translator: Haslina Haroon). Kuala Lumpur: Institut Terjemahan dan Buku Malaysia Berhad.

Honig, H.G. (1998). Complexity, contrastive linguistics and translator training: Comments on responses. In C. Schaffner (Ed.). Translation and quality (pp. 83-89). Clevedon: Multilingual Matters.

Hurtado Albir, A. \& Alves, F. (2009). Translation as a coqnitive activity. In J. Munday (Ed.). The routledge companion of translation studies (pp. 54-73). Oxon: Routledge.

Komissarov, V. N. (1991). Language and culture in translation: Competitors or collaborators', Erudit, 4(1), 33-47. Retrieved February 15, 2017, from https://www.erudit.org/fr/revues/ttr/1991-v4-n1-ttr1474/037080ar.pdf.

Pusat Pembangunan Akademik. (2016). Silibus kursus BAM1054: Pengenalan leksikografi dan penterjemahan bahasa Arab. Cyberjaya: Institut Pendidikan Guru Malaysia, Ministry of Education, Malaysia.

Pusat Penyelidikan, Pembangunan dan Inovasi. (2018). Sistem Maklumat Pelajar SMP v1.0, 30 Mac 2018. Cyberjaya: Institut Pendidikan Guru Malaysia, Ministry of Education, Malaysia.

Ressurreccio, V. M., Piorno, P.E. \& Izquierdo, I.G. (2008). 'The acquisition of translation competence through textual genre', Translation Journal, 12(4), 1-11. Retrieved April 4, 2017, from repositori.uji.es/xmlui/handle/10234/25245. 